\begin{tabular}{lcr}
\hline & ANNALES & \\
& & \\
UNIVERSITATIS MARIAE CURIE-SKLODOWSKA & \\
LOL. II & SECTIO M & 2017 \\
\hline
\end{tabular}

Jan Niemiec

Uniwersytet Jagielloński

\title{
Kierunki oddziaływania Turcji wobec wyzwań regionalnej integracji politycznej w XXI wieku
}

\section{Wstęp}

Jednym z kluczowych elementów teorii gier w stosunkach międzynarodowych jest pojęcie racjonalności, które determinuje zachowanie poszczególnych aktorów w interakcjach z innymi. W typie idealnym wszyscy uczestnicy procesu zachowują się względem siebie w sposób racjonalny, dzięki czemu interesy każdej ze stron są poszanowane i uwzględnione, a efekt rozgrywki zbliżony jest do rozwiązania kompromisowego. Niestety złożoność geopolitycznej struktury ówczesnego świata sprawia, że w praktyce niemal nie występują państwa kierujące się w swojej strategii pełną racjonalnością. Nadmiar niesprawdzonych, cząstkowych lub celowo spreparowanych informacji, które krążą współcześnie w przestrzeni medialnej, powoduje trudności w odróżnieniu prawdy od fałszu, co w efekcie przekłada się na niedoskonałość koncepcji prowadzenia polityki nawet przez najpoważniejszych graczy na arenie międzynarodowej ${ }^{1}$. Zamiast chłodnej kalkulacji i podejmowania głęboko przemyślanych, logicznych kroków, prowadzących do urzeczywistnienia zakładanych celów, w obecnych warunkach dominują czynniki emocjonalne, populistyczne czy propagandowe, a najlepiej opracowane koncepcje strategiczne oparte są na całkowicie błędnych założeniach. W takiej sytuacji w przestrzeni międzynarodowej wzrasta poczucie

1 M. Tema, Basic Assumptions in Game Theory and International Relations, "International Relations Quarterly", 2014, nr 1 (5), s. 2-3. 
niepewności, ponieważ poszczególni aktorzy nigdy nie mogą być pewni prawdziwych intencji swoich partnerów. Z tego względu spada gotowość do kooperacji i wspólnych działań w konkretnych obszarach.

Jednym z regionów świata, gdzie widoczne jest odejście od racjonalnej kalkulacji, jest Bliski Wschód. Coraz mocniej dochodzą tam do głosu resentymenty historyczne i etniczne, co w połączeniu z zagrożeniem terrorystycznym może nieść ze sobą poważne konsekwencje na przyszłość. Tym bardziej że państwo, które przez lata postrzegane było jako bezstronny mediator rozładowujący powstające tam napięcia, od jakiegoś czasu prowadzi kompletnie nieprzewidywalną politykę, w której próżno szukać racjonalności².

Celem niniejszego artykułu jest analiza i próba oceny tureckiej polityki zagranicznej pod kątem wyzwań współczesnej integracji regionalnej, a także przedstawienie kilku scenariuszy, określających możliwe kierunki przyszłego oddziaływania Republiki Turcji w regionie. Przy pomocy metody historycznej oraz analizy decyzyjnej prześledzono najważniejsze wydarzenia oraz zidentyfikowano najbardziej istotne kroki podejmowane przez decydentów w Ankarze, w sferze będącej przedmiotem zainteresowania badawczego. W przygotowaniu niniejszego tekstu szczególnie pomocne okazały się analizy tematyczne, sporządzane przez tureckie ośrodki badawcze, których autorzy mieli dostęp do najpełniejszych danych, dotyczących regionalnego zaangażowania Turcji. $\mathrm{Na}$ tej podstawie powstała hipoteza zakładająca, że obserwowana w ostatnich latach niekonsekwentna polityka regionalna Ankary wynika ze splotu szeregu czynników, wśród których na pierwszy plan wysuwają się: niekorzystne położenie międzynarodowe, brak racjonalności oraz błędne decyzje podejmowane przez rządzących.

\section{Republika Turcji - regionalne mocarstwo}

Na przestrzeni ostatnich kilkunastu lat można zaobserwować powolny proces wzrostu znaczenia Republiki Turcji na arenie międzynarodowej, co w perspektywie może zapewnić temu państwu status regionalnego mocarstwa. Mimo że zdobycie uprzywilejowanej pozycji w regionie było celem kolejnych rządów, przynajmniej od zakończenia II wojny światowej, to niestabilna sytuacja wewnętrzna Turcji, wynikająca z nierozwiązanego problemu kurdyjskiego, wojskowych zamachów stanu, wszechobecnej korupcji oraz wyraźnie zauważalnych

2 N. Anaz, M. C. Ozsahin, The Trajectory of Political Islam in Turkey, [w:] Domestic and Regional Uncertainties in the New Turkey, red. O. Tufekci, A. Chiriatti, H. Tabak, Cambridge Scholars Publishing, Cambridge 2017, s. 64-65. 
nierówności między największymi miastami a prowincją ${ }^{3}$ a także nieudolnie prowadzona polityka zagraniczna, w wyniku której Turcja była skłócona niemal ze wszystkimi swoimi sąsiadami (z wyjątkiem Azerbejdżanu), skutecznie hamowały mocarstwowe aspiracje tego państwa ${ }^{4}$. Dopiero przejęcie władzy przez umiarkowanie islamistyczną Partię Sprawiedliwości i Rozwoju (tur. Adalet ve Kalkınma Partisi - AKP) w 2002 roku odwróciło ten niekorzystny trend. Ugrupowanie pod przewodnictwem Recepa Tayyipa Erdoğana przeprowadziło szereg reform gospodarczych, mających na celu polepszenie ekonomicznej kondycji kraju oraz zbliżenie się Turcji z państwami Zachodu. Liberalizacja handlu, poprawienie systemu podatkowego oraz inwestycje infrastrukturalne na wielką skalę (szczególnie w biedniejszych regionach południowej i wschodniej Anatolii) niemal natychmiast zaprowadziły Turcję na ścieżkę wzrostu ${ }^{5}$. W tym początkowym okresie rządów AKP kluczową kwestią dla R.T. Erdoğana było możliwie jak najszybsze zakończenie negocjacji akcesyjnych z Unią Europejską, rozpoczętych w 2005 roku. Miało to być zwieńczeniem długiego okresu kontaktów z Europą, Republika pozostawała bowiem stowarzyszona ze Wspólnotami Europejskimi już od 1963 roku$^{6}$. W jednym z przemówień premier uznał wstąpienie kraju do UE za jeden z priorytetów Ankary. Podkreślił przy tym zasługi Turcji na rzecz innej organizacji zachodniego kręgu kulturowego - Organizacji Traktatu Północnoatlantyckiego ${ }^{7}$. Jednak część rządów państw Unii (przede wszystkim Grecja i Francja $)^{8}$ nie były przychylne wizji tureckiego członkostwa we Wspólnocie. Piętrzące się problemy natury formalnej, a także stopniowy spadek zainteresowania Ankary wstąpieniem do UE sprawiły, że do dzisiaj został zamknięty tylko jeden rozdział akcesyjny.

Przeszkodą dla negocjacji stał się bez wątpienia także światowy kryzys ekonomiczny, w wyniku którego turecka gospodarka odnotowała dość znaczące spadki. Wyszły przy tym na jaw pewne niedoskonałości reform strukturalnych AKP, ponieważ okazało się, że kraj jest za bardzo zależny od krótkoterminowego

3 Y. Demirhan, N. Kartal, Turgut Özal Dönemi Yoksullukla Mücadele Politikaları ve Günümüze Yansımalarl, "Journal of Business Economics and Political Science", 2014, nr 6, s. $125-129$

4 F. Ahmad, The Making of Modern Turkey, Routledge, Londyn 1993, s. 217-219.

5 F. Acar, Türkiye Ekonomisine Genel Bakış (2001-2013), „Çalışma Dünyası Dergisi”, 2013, nr 2, s. 18-19.

6 D. Kołodziejczyk, Turcja, Wydawnictwo TRIO, Warszawa 2011, s. 217.

7 T. Alaranta, Turkey under the AKP. A Critical Evaluation from the Perspective of Turkey's EUNegotiations, s.18, http://www.fiia.fi/en/publication/480/turkey_under_the_akp/,dostęp 5 X 2017.

8 E. Alessandrini, The New Turkish Foreign Policy and the Future of Turkey-EU Relations, "Istituto Affari Internazionali", 2010, nr 3, s. 11-12. 
finansowania zewnętrznego ze strony inwestorów z Zachodu. Zachwianie rynku światowego doprowadziło do natychmiastowego odpływu inwestycji zagranicznych z rynków wschodzących (a więc także i z Turcji), co tylko powiększyło deficyt budżetowy ${ }^{9}$. Wszystkie te zawirowania przyczyniły się do radykalnej zmiany priorytetów AKP w zakresie polityki zagranicznej. Pomysł ścisłej integracji z Europą został zastąpiony przez próbę odbudowania relacji z sąsiadami na Kaukazie i Bliskim Wschodzie, czego efektem miałoby być, w dłuższej perspektywie, stworzenie spójnej wizji rozwoju dla tej części świata, w czym decydujący głos powinna mieć Ankara ${ }^{10}$. Projekt ten jest tyleż ambitny, co niemal niemożliwy do wykonania. Powodem jest zarówno niezwykle skomplikowana sytuacja polityczna tego zróżnicowanego pod wieloma względami regionu, jak i bardzo niekonsekwentna polityka prowadzona przez partię R.T. Erdoğana.

\section{Relacje Turcji z państwami Bliskiego Wschodu}

Na relacjach Turcji z Bliskim Wschodem od lat ciąży przeszłość związana z istnieniem Imperium Osmańskiego, kiedy to cały ten obszar był podporządkowany władzy sułtana w Stambule. Po upadku sułtanatu i utworzeniu Republiki przez Mustafę Kemala, Turcja szukała integracji przede wszystkim z Europą, czego wyrazem było zdecydowane odcięcie się od religii w życiu publicznym państwa, gdyż sekularyzm był jednym z sześciu głównych postulatów, które ukonstytuowały współczesną Turcję $e^{11}$. Taka postawa została mocno skrytykowana przez przedstawicieli, wybijających się powoli na niepodległość, państw arabskich, dla których islam był wciąż jedną z nadrzędnych wartości. Poza tym w państwach Bliskiego Wschodu obawiano się, że władze tureckie powrócą do koncepcji ponownego zjednoczenia dawnych ziem osmańskich, tym razem pod przewodnictwem Republiki. Hasła takie pojawiały się w tureckich mediach, co było w rzeczywistości niewiele znaczącymi sloganami na użytek bieżących sporów politycznych ${ }^{12}$. Ponadto kolejne rządy tureckie nie były zbyt mocno zaangażowane w sprawy Bliskiego Wschodu, prowadząc politykę mającą na celu jedynie uzyskanie jak największych korzyści ze wzajemnej wymiany handlowej. Po zakończeniu zimnej wojny Turcja nadal opowiadała się za wizją strategicznego partnerstwa z Zachodem, dzięki czemu mogła stanowić wzór demokracji

${ }^{9}$ Ośrodek Studiów Wschodnich im. Marka Karpia, Gospodarka Turcji: sukces z niepewnymi widokami na przyszłość, https://www.osw.waw.pl/, dostęp 5 X 2017.

${ }^{10}$ A. Bank, R. Karadag, The Political Economy of Regional Power: Turkey under the AKP, „GIGA Research Unit: Institute of Middle East Studies”, 2012, nr 204, s. 6.

${ }^{11}$ D. Kołodziejczyk, op. cit., s. 147.

12 T. Alaranta, op. cit., s. 13. 
i stabilności dla państw bliskowschodnich. Jednak taka postawa Ankary wywołała falę krytyki ze strony arabskiego kręgu kulturowego, czego kulminacją był silny ostracyzm, któremu został poddany ówczesny prezydent Turcji, Süleyman Demirel, podczas szczytu Organizacji Współpracy Islamskiej w 1997 roku $^{13}$.

Punktem zwrotnym w relacjach Turcji z państwami bliskowschodnimi była decyzja ówczesnego ministra spraw zagranicznych kraju Ahmeda Davutoğlu, który nie zgodził się na otwarcie tzw. frontu tureckiego podczas drugiej wojny w Zatoce Perskiej. Faktycznym motywem tego działania była obawa przed wykształceniem się nowego kurdyjskiego organizmu państwowego po upadku władzy dyktatorskiej w Iraku, a nie chęć ograniczenia wpływów USA na Bliskim Wschodzie. Niemniej jednak twarde stanowisko A. Davutoğlu przyniosło mu sympatię ze strony państw arabskich ${ }^{14}$. Po tym sukcesie wizerunkowym rząd Turcji mógł mieć nadzieję na zaakceptowanie jej wizji regionalnej współpracy z państwami arabskimi. Pierwszym krokiem była propozycja budowy strefy wolnego handlu, która miała objąć Turcję, Syrię, Liban i Jordanię, a w perspektywie także Irak. Drugim etapem, według koncepcji ministra Davutoğlu, miało być wzajemne zniesienie wiz pomiędzy zainteresowanymi krajami ${ }^{15}$. Plany tureckiej dyplomacji pokrzyżował wybuch arabskiej wiosny i wojna w Syrii. Obecnie projekt pozostaje w zawieszeniu.

Sam minister Davutoğlu jest autorem koncepcji „strategicznej głębi”, której istotą jest utrzymywanie jak najlepszych relacji z wszystkimi regionami, z którymi łączą Turcję więzi historyczne i kulturowe, aby zapewnić sobie tym samym pozycję głównego ośrodka dla tej części świata ${ }^{16}$. Postulowane przez A. Davutoğlu zerwanie z niezdrową zależnością od zachodnich partnerów ma na celu otworzenie nowego rozdziału w historii tureckich relacji zagranicznych, gdzie za pomocą aktywnej dyplomacji, umów handlowych i współpracy bilateralnej Turcja zdobędzie stabilną pozycję jako państwo rdzenia w regionie ${ }^{17}$. Tureccy dyplomaci już od ponad dekady starają się wdrażać w życie ideę A. Davutoğlu, choć trzeba przyznać, że efekty tych działań bywają różne. W wielu przypadkach pomoc ze strony Ankary jest odrzucana ze względu na nieufność państw arabskich wobec szczerości intencji Turcji. Krytycy zarzucają Turkom zbyt daleko idące zaangażowanie się w arabskie organizacje regionalne, takie jak Liga Arab-

${ }^{13}$ K. Kirișci, The Transformation of Turkish Foreign Policy: The Rise of the Trading State, „New Perspectives on Turkey”, 2009, nr 40, s. 31.

${ }^{14}$ E. Alessandrini, op. cit., s. 2-3.

${ }^{15}$ C. Cirling, Turkey's regional power aspirations, LEP, Bruksela 2013, s. 4.

${ }^{16}$ K. Kirișci, op. cit., s. 36-37.

${ }^{17}$ Quilliam Report, Turkey's Role as a Regional Power. It' Scope, Challenges and Future, https://www.quilliaminternational.com/product-category/e-publications/, dostęp 5 X 2017. 
ska, Organizacja Współpracy Islamskiej czy Rada Współpracy Zatoki Perskiej ${ }^{18}$. Sukcesem tureckiej dyplomacji w regionie jest bez wątpienia moderowanie procesami mediacyjnymi w Palestynie, Syrii, Iranie, a nawet w Afganistanie ${ }^{19}$. Jak zauważył sam A. Davutoğlu, celem tej polityki jest stworzenie dobrego środowiska dla strukturalnej zmiany tureckiej gospodarki - przestawieniu jej z importu na eksport. W tym celu Ankara potrzebuje stworzenia pozytywnego i stabilnego klimatu w swojej najbliższej okolicy i właśnie dlatego wysiłek dyplomatyczny Turcji skupiony jest na łagodzeniu konfliktów pomiędzy jej partnerami handlowymi w myśl koncepcji współzależności Josehpa Nye'a ${ }^{20}$.

Przez długie lata mogło się wydawać, że takie racjonalne i wielowymiarowe podejście do sytuacji w regionie przyniesie Turcji istotne korzyści. Integracja polityczna i regionalna z państwami arabskimi była na tyle owocna, że w pewnym momencie R.T. Erdoğan był najpopularniejszym politykiem na całym Bliskim Wschodzie, co potwierdzały badania opinii publicznejej ${ }^{21}$. Turcja, kraj leżący na granicy Bliskiego Wschodu i Europy, posiadająca poprawne relacje z wszystkimi ważnymi graczami oraz niezaangażowana $\mathrm{w}$ regionalne spory i podziały, była postrzegana jako idealny kandydat na bezstronnego arbitra i mediatora ${ }^{22}$.

Niestety, na polityce zagranicznej Turcji wobec sąsiadów od lat ciąży piętno niepewnej sytuacji wewnętrznej, kształtowanej głównie przez nigdy nie wygaszony konflikt z Kurdami ${ }^{23}$. Problem kurdyjski jest także jednym z głównych czynników, przez które Republika Turcji zaczęła tracić swoją regionalną pozycję pod koniec ubiegłej dekady. Wydawało się, że dzięki poprawnym relacjom, jakie rząd turecki nawiązał z irackimi Kurdami, którzy zdobyli szeroką autonomię po upadku reżimu Saddama Husajna, łatwiej będzie unormować relacje z kurdyjską mniejszością w Anatoliii ${ }^{24}$. Tak się jednak nigdy nie stało. Pierwszym symptomem zmiany przewidywalnej dotychczas polityki był atak wojsk tureckich na bazy treningowe członków terrorystycznej Partii Pracujących Kurdystanu, zlokalizowane w północnym Iraku, do którego doszło na przełomie 2007 i 2008 $\mathrm{roku}^{25}$. Starcia w Iraku nie trwały długo, ale stanowiły poważne ostrzeżenie dla społeczności międzynarodowej wobec intencji Turcji w regionie. Kolejnym

\footnotetext{
${ }^{18}$ C. Cirling, op. cit., s. 4.

${ }^{19}$ K. Kirișci, op. cit., s. 40.

${ }^{20}$ Ibidem, s. 42.

${ }^{21}$ A. Bank, R. Karadag, op. cit., s. 14.

${ }^{22}$ Ibidem, s. 17-18.

${ }^{23}$ Y. Elicin, The Europeization of Turkey: Reform in Local Governments, „International Journal of Economic and Administrative Studies", 2011, nr 7, s. 117.

${ }^{24}$ E. Alessandrini, op. cit., s. 9.

${ }^{25}$ K. Kirișci, op. cit., s. 30-31.
} 
potknięciem były niewłaściwie prowadzone negocjacje w sprawie programu nuklearnego Iranu w 2011 roku. W wyniku szeregu błędów dyplomatycznych nastroje na linii Ankara-Teheran uległy znacznemu pogorszeniu. Oba kraje dopiero stosunkowo niedawno powróciły do bardziej efektywnej polityki, na co wpływ ma ich zaangażowanie w Syrii ${ }^{26}$.

Turecka wizja braku problemów w kontaktach z sąsiadami została całkowicie pogrzebana podczas wybuchu arabskiej wiosny. Natychmiastowe opowiedzenie się po stronie sił opozycyjnych podczas starć w Egipcie, Libii, Tunezji i Syrii spowodowało zgrzyt $w$ relacjach z tamtejszymi władzami ${ }^{27}$. Ankara nie potrafiła jednak właściwie zareagować na dalszy rozwój wydarzeń. Nieprzewidywalność tureckiej polityki zagranicznej objawiła się w pełni podczas wojny w Syrii. Niejasne kontakty z bojownikami tak zwanego Państwa Islamskiego (oskarżenia o handel ropą), walka z syryjskimi Kurdami, powstrzymującymi terrorystów, sinusoida w relacjach z zaangażowaną w konflikt Rosją (od zestrzelenia rosyjskiego samolotu po wspólne wizje R.T. Erdoğana i Władimira Putina w kwestii zakończenia walk), dyplomatyczna rywalizacja z Iranem, oficjalne wkroczenie wojsk tureckich do Syrii, mające na celu obalenie reżimu Baszara el-Asada ${ }^{28}$. W obliczu tego złożonego i niejednoznacznego konfliktu działania Ankary są co najmniej dwuznaczne. Obecnie Turcja jest jednym z mediatorów wdrożenia procesu pokojowego, ale w powszechnej opinii kluczowe decyzje dla Syrii zostaną podjęte przez przedstawicieli Rosji i Iranu, który od kilku lat stopniowo odblokowuje swoje relacje z USA ${ }^{29}$.

\section{Relacje Turcji z państwami Kaukazu Południowego}

W przypadku Kaukazu Południowego Turcja przez długi czas utrzymywała poprawne relacje jedynie z Azerbejdżanem. Tradycyjny sojusz tych dwóch bliskich kulturowo państw był wzmacniany przez ożywioną wymianę handlową. Stosunki z Gruzją były neutralne, natomiast na linii Ankara-Erywań istniała wzajemna wrogość. Miało to związek z oskarżeniami Armenii o rzeź Ormian, mieszkańców Imperium Osmańskiego, która miała zostać dokonana w 1915

${ }^{26}$ S. Elik, Ahmedinejad Sonrası Türkiye-İran İlişkileri, “Ilmi Etüdler Derneği”, 2014, nr 1, $3-6$.

${ }^{27}$ C. Cirling, op. cit., s. 6.

${ }^{28}$ S. Mercan, Perceptions of Security in Turkish Foreign Policy toward the Middle East in the 21st Century, [w:] Turkey's Foreign Policy and Security Perspectives in the 21st Century, red. S. Demir, BrownWalker Press, Boca Raton 2016, s. 111-115.

${ }^{29}$ E. İsmayll, Cenevre'de Suriye Krizinin Geleceği ve Rusya, "Bilgesam Analiz", 2017, nr 1359, s. 5. 
roku. Turcy odpierali te zarzuty, twierdząc, że przymusowe przesiedlenia ludności ormiańskiej miały związek z zagrożeniem ze strony Rosji, która atakującej osmańskie pozycje we wschodniej Anatolii. Kwestia uznania tych wydarzeń za ludobójstwo nie została do dzisiaj oficjalnie wyjaśniona i od lat stanowi główną przyczynę konfliktu politycznego między Turcją a Armenią ${ }^{30}$. Ważna dla sytuacji w tym regionie świata jest także kwestia przynależności Górskiego Karabachu, spornego terytorium, do którego prawa roszczą sobie zarówno Armenia, jak i Azerbejdżan ${ }^{31}$.

Zgodnie z realizacją polityki „strategicznej głębi”, rząd AKP musiał nadać nowy impuls dla związków z Gruzją, a także spróbować poprawić swoje relacje z Armenią przy jednoczesnym zachowaniu silnych więzi z Azerbejdżanem. Istotną kwestią było także powstrzymanie ekspansji Rosji, której wpływy na Kaukazie zaczęły rosnąć po objęciu władzy prezydenckiej przez W. Putina. Jednak wkrótce okazało się, że zaangażowanie AKP w sprawy regionu ma przede wszystkim wymiar ekonomiczny. Gdy Ankarze udało się nawiązać pozytywne relacje z Bliskim Wschodem, natychmiast porzucono wizję odbudowy znaczenia Turcji za wschodnimi granicami i skupiono się na zacieśnianiu więzów z krajami arabskimi. Natomiast na Kaukazie zadowolono się czerpaniem korzyści z handlu surowcami z Rosją ${ }^{32}$.

Taka sytuacja utrzymywała się do momentu rosyjskiej agresji na Gruzję. Rząd turecki nie stanął jednak murem za swoim mniejszym sąsiadem, a jedynie zaproponował powołanie Kaukaskiej Platformy Stabilności i Rozwoju w 2008 roku. W obliczu intensyfikacji działań wojennych powodzenie tej inicjatywy nie miało praktycznie żadnych szans, natomiast wpisywało się doskonale w turecką „strategiczną głębię". Idea Platformy jako miejsca na rozwiązywanie sporów między państwami Kaukazu, Turcją i Rosją była dobrym pomysłem taktycznym, ukazującym Ankarę jako niezależnego mediatora i rozjemcę, niemniej jednak jej wartość merytoryczna była w rzeczywistości niewielka ${ }^{33}$. Neutralność turecka w sporze Rosji z Gruzją faktycznie wzmacniała Moskwę, której oficjalnie nie sprzeciwiło się żadne mocarstwo. Dostępu do Platformy nie miały także państwa

${ }^{30}$ S. Laçiner, Türkler ve Ermeniler: Bir Uluslararası İlişkiler Çalışması, USAK Yayınları, Ankara 2005, s. 361-366.

${ }^{31}$ M. Çelikpala, Türkiye ve Kafkasya: Reaksiyoner Dış Politikadan ProaktifRitmik Diplomasiye Geçiş, „Uluslararası İlişkiler”, 2010, nr 25, s. 98-100.

${ }^{32}$ E. Şahin, Ana Hatlarılla Türklerin Kafkasya Politikaları: Başlangıcından Günümüze Genel Bir Değerlendirme,"Yeni Türkiye", 2015, nr 71, s. 474-476.

${ }^{33}$ K. Zasztowt, Relacje Turcji z Kaukazem Południowym i ich znaczenie dla Unii Europejskiej, [w:] Turcja i Europa. Wyzwania i Szanse, red. A. Szymański, Polski Instytut Spraw Międzynarodowych, Warszawa 2011, s. 188-191. 
nienależące do regionu, a więc USA i UE nie mogły angażować się w ten projekt i kontrolować poczynań Rosji ${ }^{34}$.

Próba stworzenia regionalnej instytucji, mającej na celu zapewnienie stabilności i współpracy w regionie Kaukazu pod tureckim zwierzchnictwem, nie przyniosła Ankarze spodziewanych korzyści. W praktyce okazało się, że pozycja negocjacyjna Rosji wobec państw tego obszaru jest nieporównywalnie silniejsza, a dyplomacja Turcji nie potrafiła przedstawić im atrakcyjniejszej wizji. Efektem takiego rozwoju wydarzeń jest fakt, że turecka obecność w regionie Kaukazu w dziedzinie polityki międzynarodowej ma znaczenie symboliczne. Znacznie trwalsze są więzi ekonomiczne łączące Turcję z tym obszarem świata. Największym sukcesem dyplomacji R.T. Erdoğana w regionie pozostaje więc podpisanie protokołów dyplomatycznych z Armenią, mających w przyszłości doprowadzić do normalizacji stosunków pomiędzy oboma państwami. Sam proces jest jednak długotrwały ze względu na historyczne zaszłości oraz odmienne wizje rozwoju relacji na linii Ankara-Erywań ${ }^{35}$.

Koncepcja strategicznej głębi w odniesieniu do regionu Kaukazu nie przyniosła oczekiwanych efektów. Okazało się, że Turcja nie posiada wystarczająco przekonujących instrumentów, aby jednocześnie unormować swoje związki z Armenią i utrzymywać silne więzi z Azerbejdżanem. Niewątpliwie rząd AKP postawił sobie w tym przypadku zdecydowanie zbyt ambitne zadania, których nie był w stanie zrealizować. Z powodu błędnie poprowadzonej polityki regionalnej obecnie Turcja może liczyć jedynie na pozytywne relacje ekonomiczne z władzami Baku i Tbilisi. Natomiast porażka Ankary na Kaukazie oznacza coraz silniejszą pozycję Rosji, która widoczna jest przede wszystkim w jej kontaktach z Armenią.

\section{Scenariusze rozwoju regionalnej integracji politycznej - perspektywa turecka}

Analiza relacji Turcji z państwami Bliskiego Wschodu i Kaukazu Południowego pozwala na zbudowanie kilku scenariuszy rozwoju integracji regionalnej, gdzie głównym wyznacznikiem będzie określenie wektora aktywności politycznej Ankary. Położenie nacisku na stabilizację wewnętrzną w sposób istotny osłabi tendencję do zwiększonego zaangażowania na arenie międzynarodowej. Z kolei

${ }^{34}$ M. Monshipouri, Pipeline Politics in Iran, Turkey and the South Caucasus, [w:] The Great Game in West Asia: Iran, Turkey and the South Caucasus, red. M. Kamrava, Oxford University Press, Nowy Jork 2016, s. 53-55.

${ }^{35}$ C. Cirling, op. cit., s. 3. 
wzmożona ofensywa dyplomatyczna może przełożyć się w dłuższej perspektywie na odzyskanie przez Turcję pozycji regionalnego lidera, ale wiąże się jednocześnie z ryzykiem zaniedbania sytuacji wewnątrzkrajowej, gdzie władze zmagają się z siłami opozycyjnymi i kurdyjskimi bojówkami we wschodniej Anatolii.

Pierwszy ze scenariuszy zakłada, że w obliczu braku trwałych efektów realizowanej przez AKP koncepcji „strategicznej głębi”, Turcja powróci do ściślejszych i bardziej pozytywnych kontaktów z Unią Europejską. Jednak z całą pewnością przyszłe relacje Brukseli z Ankarą będą musiały zostać poważnie przedefiniowane, dotychczasowy proces akcesyjny od lat pogrążony jest bowiem w stagnacji. Nowego dynamizmu w tym przypadku może nadać próba wspólnego rozwiązania problemu migracyjnego, ale wymaga to równorzędnego zaangażowania obu stron ${ }^{36}$. Z pewnością pomogłoby to także odbudowie wizerunku Turcji jako państwa dążącego do regionalnej stabilizacji. Wiele w tym wypadku będzie zależeć od decyzji Niemiec i Francji, dwóch najsilniejszych państw UE, których dominację wzmocnił niedawny brexit.

Jednakże kolejną poważną przeszkodą w odbiorze Turcji na arenie międzynarodowej jest przeprowadzona ostatnio zmiana ustroju, z parlamentarnego na prezydencki, gwarantująca prezydentowi R.T. Erdoğanowi niespotykane w republikańskiej tradycji kraju kompetencje ${ }^{37}$. Mimo że reforma modelu ustrojowego została poparta przez społeczeństwo w ogólnonarodowym referendum, zdaniem opozycji wyniki głosowania zostały sfałszowane na dużą skalę, co jeszcze bardziej obniża wiarygodność R.T. Erdoğana i jego obozu. Obecnie trudno przewidzieć, jak ta radykalna zmiana ustroju wpłynie na zachowanie Turcji w relacjach $\mathrm{z}$ innymi państwami, ale można zakładać, że tak doświadczony polityk, jak R.T. Erdoğan będzie dążył najpierw do ustabilizowania sytuacji wewnętrznej, więc nie należy się w najbliższym czasie spodziewać nadmiernie aktywnej polityki zagranicznej ze strony Ankary. Z punktu widzenia rozwoju integracji regionalnej scenariusz ten nie jest korzystny, ponieważ podejmowane dotychczas na arenie międzynarodowej działania tureckiej dyplomacji zostaną ograniczone, a sam proces może na długi czas pogrążyć się w stagnacji. Wiele zależy od tego, jak szybko prezydent Erdoğan zdoła przekonać niechętną zmianom ustrojowym część społeczeństwa do słuszności swojej koncepcji. Mimo niewątpliwych zdolności R.T. Erdoğana, może się to okazać największym wyzwaniem w jego politycznej karierze.

${ }^{36}$ E. Çarmıklı, M. Kader, Türkiye'de Göçmen Kaçakçıllğı: Mülteci Krizinin 'Öteki' Yüzü, "USAK Raporlari", 2016, nr 45, s. 35-38.

37 A. Gül, Milletin Özne Olduğu Sistem: Cumhurbaşkanlı̆̆ Hükümet Sistemi, "Yeni Türkiye”, 2017, nr 94, s. 5-9. 
W drugim scenariuszu Turcja stawia na zwiększenie wysiłków na rzecz integracji regionalnej. Być może seria porażek dyplomatycznych zmusi Ankarę do ponownego przedefiniowania swojej polityki zagranicznej względem regionu i wymusi ściślejszą kooperację ze swoimi sąsiadami w ramach organizacji międzynarodowych. O ile relacje Turcji z UE są obecnie dość chłodne, to konflikt w Syrii i powstanie tak zwanego Państwa Islamskiego uzmysłowiło Ankarze, że bez wsparcia NATO ciężko będzie w pojedynkę przywrócić regionowi niezbędne poczucie stabilności ${ }^{38}$. Turcja wykazuje także większą aktywność w pracach Globalnego Forum Antyterrorystycznego, unikalnej platformy międzynarodowej, której zadaniem jest faktyczne zapobieganie ekstremizmowi poprzez skupienie się na samym źródle problemu ${ }^{39}$. W ostatnim czasie można zauważyć stopniowe wycofanie się z polityki „strategicznej głębi” na rzecz bardziej pragmatycznego podejścia, zakładającego bliższe relacje z najpotężniejszymi graczami w konkretnym regionie. Ma to związek $\mathrm{z}$ odejściem od próby ustanawiania dobrych kontaktów ze wszystkimi aktorami na danym obszarze, ponieważ wiele przypadków w przeszłości (a szczególnie efekty arabskiej wiosny, kiedy to obalenie autorytarnych reżimów nie wiązało się z przekształceniem państw regionu w imię „tureckiego modelu muzułmańskiej demokracji” ${ }^{40}$ nauczyło Ankarę, że w obliczu sprzecznych interesów wizja A. Davutoğlu po prostu nie działa. Wytrwały upór przy forsowaniu tej polityki mógłby przynieść więcej szkód dla międzynarodowego wizerunku Turcji ${ }^{41}$.

$\mathrm{Z}$ kolei według trzeciego scenariusza Turcja jest skazana na poszukiwanie sojuszników, w porozumieniu z którymi byłaby w stanie realizować swoje interesy regionalne. Owocna współpraca z Iranem jest w dzisiejszych warunkach niemożliwa, przede wszystkim ze względów ideologicznych. Również najpotężniejsze państwa arabskie są aktualnie rozczarowane postawą Ankary, która nie wsparła ich sankcji przeciwko Katarowi ${ }^{42}$. Z tych względów jedynym „dostępnym” partnerem dla Turcji pozostaje Federacja Rosyjska. Mimo że z historycznego punktu widzenia relacje turecko-rosyjskie przez wieki były naznaczone przez konflikt i rywalizację o terytoria (Bałkany, Kaukaz, cieśniny czarnomorskie) ${ }^{43}$, nie sposób nie dostrzec silnych więzi ekonomicznych, wykształconych w minionych latach pomiędzy

\footnotetext{
${ }^{38}$ C. Cirling, op. cit., s. 7-8.

${ }^{39}$ F. Ahmad, op. cit., s. 9.

${ }^{40}$ Ibidem, s. 2.

${ }^{41}$ T. Alaranta, op. cit., s. 12-13.

${ }^{42}$ B. Erkin, Değişen ABD Politikalarının Bir Yansıması Olarak Katar Krizi, "TASAV Dış Politika Araștırmaları Merkezi", 2017, nr 25, s. 1-4.

${ }^{43}$ J. P. Roux, Türklerin Tarihi. Pasifik'ten Akdeniz'e 2000 Yll, Kabalci Yaymevi, Stambuł
} 2002, s. 422-430. 
oboma państwami, widocznych szczególnie w wymianie handlowej, turystyce i sektorze energetycznym ${ }^{44}$. Sprzeczne interesy w odniesieniu do wojny w Gruzji, inwazji na Krym czy wspomnianej wyżej arabskiej wiosny, choć powodowały ostre spory $\mathrm{i}$ kryzysy zaufania, w ogólnym rozrachunku nie przekreślały prowadzonych równolegle starań na rzecz utrzymania pozytywnego bilansu relacji ${ }^{45}$.

Obecnie stosunki turecko-rosyjskie zdają się przeżywać fazę największego rozkwitu od dziesięcioleci. Ma to związek także z tym, że prezydent R.T. Erdoğan stopniowo upodabnia ustrój Turcji do modelu rządzenia krajem, który stworzył w Rosji W. Putin. Podobna forma rządów, w połączeniu z żywioną przez obu liderów chęcią wyparcia z tej części świata wpływów Unii Europejskiej i Stanów Zjednoczonych, może zakończyć się próbą zawiązania trwałego sojuszu Ankary z Kremlem. O ile na razie taka wizja jest daleka od realizacji (Turcję i Rosję wciąż dzieli wiele kluczowych kwestii, na przykład percepcja bezpieczeństwa) ${ }^{46}$, to w szerszym horyzoncie czasowym powodzenie takiej inicjatywy nie jest wykluczone. Tym bardziej jeśli R.T. Erdoğan całkowicie odrzuci dotychczasowy dorobek tureckiej dyplomacji, wypracowany przez AKP, i skupi się na wdrażaniu określonych celów strategicznych w regionie. Oczywiście działanie w tandemie z Rosją wiąże się z ryzykiem wykorzystania Turcji przez potężniejszego partnera, czego Ankara doświadczyła już w przypadku Kaukazu Południowego. Zakładając jednak, że dynamika procesów zachodzących na arenie międzynarodowej nadal będzie działać na niekorzyść Republiki Turcji, prezydent R.T. Erdoğan stanie przed koniecznością podjęcia współpracy z jednym ze światowych mocarstw. Z przytoczonych wyżej argumentów wynika, że najlepiej w tej roli odnalazłaby się właśnie Rosja.

Ostatni ze scenariuszy przewiduje zwiększenie tureckiego zaangażowania na Bałkanach. Wpisywałoby się to w szerszy kontekst odzyskiwania wpływów na terenach byłego Imperium Osmańskiego, choć w założeniach koncepcji priorytet nadano poprawie stosunków z Bliskim Wschodem i Kaukazem Południowym. Jednak niewątpliwe porażki tej inicjatywy, o czym wspomniano we wcześniejszych podrozdziałach niniejszego artykułu, mogą skłonić decydentów w Ankarze do modyfikacji obowiązującej strategii i zwrócenia się w kierunku państw bałkańskich. Zważywszy na te uwarunkowania, niezwykle istotny jest fakt, że od kilku lat rząd turecki prowadzi aktywną politykę promocji kultury muzułmańskiej w Bośni i Hercegowinie oraz Kosowie ${ }^{47}$. Dodając do tego coraz poważniejsze zaangażowanie

\footnotetext{
${ }^{44}$ M. Koçak, Türkiye - Rusya ilişkileri, "SETA”, 2017, nr 201, s. 9-13.

${ }^{45}$ S.. Aktürk, The Crisis in Russian-Turkish Relations, 2008-2015, "ETH Zurich", 2016, nr 179, s. 2-4.

${ }^{46}$ M. Koçak, op. cit., s. 14-17.

${ }^{47}$ M. U. Ekinci, Türkiye - Balkanlar ilişkileri, "SETA”, 2017, nr 204, s. 11-12.
} 
kapitałowe inwestorów znad Bosforu na Bałkanach (największe w Bośni i Kosowie, ale tureckie przedsiębiorstwa zdobywają rynki krajowe także w Macedonii, Albanii i Serbii) ${ }^{48}$, można zakładać, że południowy wschód Europy zyskuje na znaczeniu w planach rządu AKP i prezydenta R.T. Erdoğana na regionalną ekspansję.

Jednak, dla zdobycia silnej pozycji na tym obszarze, Turcja musi liczyć na zbieg korzystnych okoliczności, wśród których najistotniejszy będzie przedłużający się kryzys w UE, co przełoży się na brak zainteresowania pozostałych państw bałkańskich wizją członkostwa w strukturach Wspólnoty. Ponadto turecka oferta regionalnej współpracy powinna być korzystniejsza od posunięć Federacji Rosyjskiej, dla której Bałkany są także niezwykle istotnym z geopolitycznego punktu widzenia terenem.

\section{Podsumowanie}

Ostatnie wydarzenia świadczą o tym, że, mimo długotrwałych starań i zabiegów dyplomatycznych, pozycja Turcji na arenie międzynarodowej jest wciąż zbyt słaba, aby Ankara mogła bez przeszkód realizować swoje mocarstwowe aspiracje $\mathrm{w}$ regionie. Jedną z głównych przyczyn takiego stanu rzeczy jest niespokojna sytuacja wewnętrzna. Krajem co jakiś czas wstrząsają krwawe zamachy terrorystyczne, a po nieudanym zamachu stanu z lipca ubiegłego roku do więzień trafiło prawie 60 tys. ludzi, a ponad 140 tys. straciło pracę ${ }^{49}$. Prezydent Erdoğan poszerza zakres swojej władzy w imię walki z „wrogami narodu” (kurdyjscy bojownicy, islamscy terroryści, ale także nastawieni proeuropejsko mieszkańcy metropolii), przekształcając stopniowo turecki model demokracji w autorytarną dyktaturę $e^{50}$. Takie działania podają w wątpliwość sens kontynuowania procesu akcesyjnego do Unii Europejskiej, a tym samym Turcja coraz bardziej oddala się od zachodniego kręgu kulturowego.

Alternatywna dla członkostwa w UE koncepcja „regionalnego mocarstwa” także napotyka na poważne przeszkody. Ze względu na opisane wyżej dość chaotyczne relacje z państwami obszaru Bliskiego Wschodu i Kaukazu, Turcja traci powoli na znaczeniu. W regionalnej wizji R.T. Erdoğana jego kraj miał być stabilnym państwem rdzenia, ale niekonsekwentna i błędna polityka zagraniczna znacznie obniżyła rangę Turcji. W efekcie obecnie mocniejszą pozycję w regionie Bliskiego Wschodu zdobyły takie państwa, jak Iran i Arabia Saudyjska, które

\footnotetext{
${ }^{48}$ A. Vračić, Turkey's Role in the Western Balkans, "Stiftung Wissenschaft und Politik", 2016, nr 11, s. $12-26$.

${ }^{49}$ Turkey purge, https://turkeypurge.com/, dostęp 5 X 2017.

${ }^{50}$ M. Chudziak, Przez Czystki ku „Nowej Turcji” - finalna faza przebudowy państwa, „Ośrodek Studiów Wschodnich im. Marka Karpia”, 2016, nr 228, s. 2.
} 
dzięki zdecydowanie bardziej racjonalnemu podejściu o wiele lepiej odnajdują się w zmiennej rzeczywistości. Samotność Turcji na arenie międzynarodowej potęguje także antyglobalistyczna retoryka R.T. Erdoğana. Niechęć w dzieleniu się władzą z podmiotami niepaństwowymi i brak zaufania do nowych instytucji powoduje, że tak duże i niejednorodne państwo jak Turcja pogrąża się w impasie i traci możliwości rozwoju ${ }^{51}$. Wśród postawionych sobie przez AKP w 2010 roku ambitnych celów strategicznych na najbliższą dekadę (członkostwo w UE, pogłębiona regionalna integracja, wykształcenie skutecznego mechanizmu rozwiązywania konfliktów, silna pozycja w organizacjach międzynarodowych, dołączenie do najbardziej rozwiniętych krajów świata ${ }^{52}$, każdy wydaje się odleglejszy od pełnej realizacji niż w momencie początkowym. Należy przy tym zaznaczyć, że duży wpływ na załamanie się międzynarodowej pozycji Turcji w regionie miało przeniesienie części kompetencji dyplomatycznych ministra spraw zagranicznych A. Davutoğlu na rzecz R.T. Erdoğana ${ }^{53}$.

Odtąd Turcja stała się nieprzewidywalnym uczestnikiem, toczącej się na arenie stosunków międzynarodowych, rozgrywki, a wiele jej posunięć wymyka się z ram obiektywnie pojmowanej racjonalności. Biorąc na siebie większą odpowiedzialność w zakresie kształtowania polityki zagranicznej, prezydent Erdoğan liczył zapewne na skrócenie procesu decyzyjnego, co miało zapewnić mu przewagę sytuacyjną nad innymi graczami. Niestety, jego konfrontacyjna postawa i wynikające z niej założenie o konieczności podjęcia rywalizacji z innymi aktorami na arenie międzynarodowej, przynosi efekty odmienne od zakładanych. Dążenie do maksymalizacji własnych zysków kosztem innych państw zamyka przed Turcją możliwość kooperacji, która w dzisiejszym, pełnym współzależności świecie ma ogromne znaczenie.

Nie jest pewne, czy prezydent Erdoğan jest świadomy ułomności i swoistej krótkowzroczności prowadzonej przez siebie polityki. Być może ta z pozoru chaotyczna i niekonsekwentna polityka jest częścią większego planu, w wyniku którego Turcja zrealizuje swoje strategiczne cele w regionie. Prowadzenie skutecznych działań często zależy w dużym stopniu od idei i przekonań. Turcja Erdoğana jest z pewnością przekonana o swojej sile. Słuszność koncepcji prezydenta będzie można ocenić dopiero w dłuższej perspektywie, natomiast już teraz widać wyraźnie, że oparcie się na samej współpracy ekonomicznej przy jednoczesnej niechęci do pogłębionej integracji politycznej może znacząco ogra-

${ }^{51}$ N. Hüsnüoğlu, E. Altınel, The Role of Regional Development Agencies in Turkey, „Social inequality and economic growth", 2012, nr 28, s. 140-141.

${ }^{52}$ C. Cirling, op. cit., s. 1.

${ }^{53}$ A. Brock, Turkey: An Emerging Power in a Changing Middle East, Council on Foreign Relations, Stambuł 2014, s. 3-4. 
niczyć zdolność do skutecznego oddziaływania na swoich partnerów. Niemniej klucze do rozwiązania tej kwestii leżą w rękach prezydenta Turcji. Tylko od niego zależy, jak będzie z nich korzystał.

\section{Bibliografia}

- Acar F., Türkiye Ekonomisine Genel Bakış (2001-2013), „Çalışma Dünyası Dergisi”, 2013, nr 2.

- Ahmad F., The Making of Modern Turkey, Routledge, Londyn 1993.

- Aktürk S., The Crisis in Russian-Turkish Relations, 2008-2015, "ETH Zurich”,2016, nr 179.

- Alaranta T., Turkey under the AKP. A Critical Evaluation from the Perspective of Turkey's EU Negotiations, http://www.fiia.fi/en/publication/480/turkey_under_the_akp/, dostęp 5 X 2017.

- Alessandrini E., The New Turkish Foreign Policy and the Future of Turkey-EU Relations, "Istituto Affari Internazionali", 2010, nr 3.

- Anaz N., Ozsahin M. C., The Trajectory of Political Islam in Turkey, [w:] Domestic and Regional Uncertainties in the New Turkey, red. O. Tufekci, A. Chiriatti, H. Tabak, Cambridge Scholars Publishing, Cambridge 2017.

- Bank A., Karadag R., The Political Economy of Regional Power: Turkey under the AKP, „GIGA Research Unit: Institute of Middle East Studies”, 2012, nr 204.

- Brock A., Turkey: An Emerging Power in a Changing Middle East, Council on Foreign Relations, Stambuł 2014.

- Chudziak M., Przez Czystki ku „Nowej Turcji” - finalna faza przebudowy państwa, „Ośrodek Studiów Wschodnich im. Marka Karpia”, 2016, nr 228.

- Cirling C., Turkey's regional power aspirations, LEP, Bruksela 2013.

- Çarmıklı E., Kader M., Türkiye'de Göçmen Kaçakçıllğgl: Mülteci Krizinin 'Öteki' Yüzü, "USAK Raporlari”, 2016, nr 45.

- Çelikpala M., Türkiye ve Kafkasya: Reaksiyoner Dıș Politikadan ProaktifRitmik Diplomasiye Geçiş, „Uluslararası İlişkiler”, 2010, nr 25.

- Demirhan Y., Kartal N., Turgut Özal Dönemi Yoksullukla Mücadele Politikaları ve Günümüze Yansımalarl, "Journal of Business Economics and Political Science", 2014, nr 6.

- Ekinci M. U., Türkiye - Balkanlar ilişkileri, “SETA”, 2017, nr 204.

- Elicin Y., The Europeization of Turkey: Reform in Local Governments, „International Journal of Economic and Administrative Studies", 2011, nr 7.

- Elik S., Ahmedinejad Sonrası Türkiye-İran İlişkileri, "Ilmi Etüdler Derneği”, 2014, nr 1.

- Erkin B., Değișen ABD Politikalarının Bir Yansıması Olarak Katar Krizi, "TASAV Dış Politika Araştırmaları Merkezi", 2017, nr 25.

- Gül A., Milletin Özne Olduğu Sistem: Cumhurbaşkanlığı Hükümet Sistemi, "Yeni Türkiye", 2017, nr 94.

- Hüsnüoğlu N., Altınel E., The Role of Regional Development Agencies in Turkey, „Social inequality and economic growth", 2012, nr 28.

- İsmayıl E., Cenevre'de Suriye Krizinin Geleceği ve Rusya, "Bilgesam Analiz", 2017, nr 1359. 
- Kirişci K., The Transformation of Turkish Foreign Policy: The Rise of the Trading State, „New Perspectives on Turkey”, 2009, nr 40.

- Koçak M., Türkiye - Rusya ilişkileri, "SETA”, 2017, nr 201.

- Kołodziejczyk D., Turcja, Wydawnictwo TRIO, Warszawa 2011.

- Laçiner S., Türkler ve Ermeniler: Bir Uluslararası İlişkiler Çalışması, USAK Yayınları, Ankara 2005.

- Mercan S., Perceptions of Security in Turkish Foreign Policy toward the Middle East in the 21st Century, [w:] Turkey's Foreign Policy and Security Perspectives in the 21st Century, red. S. Demir, BrownWalker Press, Boca Raton 2016.

- Monshipouri M., Pipeline Politics in Iran, Turkey and the South Caucasus, [w:] The Great Game in West Asia: Iran, Turkey and the South Caucasus, red. M. Kamrava, Oxford University Press, Nowy Jork 2016.

- Ośrodek Studiów Wschodnich im. Marka Karpia, Gospodarka Turcji: sukces z niepewnymi widokami na przyszłość, https://www.osw.waw.pl/, dostęp 5 X 2017.

- Quilliam Report, Turkey's Role as a Regional Power. It' Scope, Challenges and Future, https://www.quilliaminternational.com/product-category/e-publications/, dostęp 5 X 2017.

- Roux J. P., Türklerin Tarihi. Pasifik'ten Akdeniz'e 2000 Yll, Kabalci Yaymevi, Stambuł 2002.

- Şahin E., Ana Hatlarıyla Türklerin Kafkasya Politikaları: Başlangıcından Günümüze Genel Bir Değerlendirme,"Yeni Türkiye", 2015, nr 71.

- Tema M., Basic Assumptions in Game Theory and International Relations, "International Relations Quarterly", 2014, nr 1 (5).

- Turkey purge, https://turkeypurge.com/, dostęp 5 X 2017.

- Vračić A., Turkey's Role in the Western Balkans, "Stiftung Wissenschaft und Politik", 2016, nr 11.

- Zasztowt K., Relacje Turcji z Kaukazem Południowym i ich znaczenie dla Unii Europejskiej, [w:] Turcja i Europa. Wyzwania i Szanse, red. A. Szymański, Polski Instytut Spraw Międzynarodowych, Warszawa 2011.

Streszczenie: Celem niniejszej pracy jest analiza i próba oceny tureckiej polityki zagranicznej pod kątem wyzwań współczesnej integracji regionalnej. W części pierwszej zostały przedstawione czynniki determinujące obecną pozycję Turcji w regionie, ze szczególnym uwzględnieniem dorobku sprawującej rządy nieprzerwanie od 2002 roku Partii Sprawiedliwości i Rozwoju. Następnie prześledzono działania tureckich władz względem Bliskiego Wschodu i Kaukazu Południowego dwóch kluczowych regionów, stanowiących alternatywę dla stopniowo pogarszających się relacji Republiki Turcji z Unią Europejską. Ostatnia część pracy stanowi próbę określenia tendencji, mających wpływ na proces kształtowania się przyszłej polityki integracyjnej Ankary w odniesieniu do najbliższych sąsiadów.

Słowa kluczowe: Republika Turcji, integracja regionalna, Partia Sprawiedliwości i Rozwoju, Bliski Wschód, Kaukaz Południowy 


\section{Directions of Turkish Influence in Light of Challenges for Regional Political Integration in the $21^{\text {st }}$ Century}

Summary: The purpose of this paper is to analyze and to evaluate Turkish foreign policy in view of the challenges of contemporary regional integration. The first part presents the factors determining the current position of Turkey in the region, with particular regard to the the policy pursued by the Justice and Development Party, which has been in power since 2002. Next part focuses on the actions of the Turkish authorities towards the Middle East and the South Caucasus - two key regions, which are an alternative to the gradually deteriorating relations between the Republic of Turkey and the European Union. The final part of the paper is an attempt to identify trends that will influence Ankara's future integration policy in relation to its closest neighbors.

Keywords: Republic of Turkey, regional integration, Justice and Development Party, Middle East, South Caucasus 